\title{
15th international Workshop on Computer-Aided Diagnosis
}

Chairman: Kunio Doi, PhD (USA), Co-Chair: Ulrich Bick, MD (D) 